\title{
Correction to: Concussion killjoys: CTE, violence and the brain's becoming
}

\author{
$\operatorname{Aryn}_{\text {Martin}^{1}}$ (D) Alasdair McMillan ${ }^{1}$
}

Published online: 5 March 2021

(C) The Author(s) 2021

\section{Correction to: BioSocieties https://doi.org/10.1057/s41292-020-00209-1}

The article Concussion killjoys: CTE, violence and the brain's becoming, written by Aryn Martin and Alasdair McMillan, was originally published electronically on the publisher's internet portal on 30 October 2020 without open access. With the author(s)' decision to opt for Open Choice the copyright of the article changed on 9 February 2021 to (C) The Author(s) 2021 and the article is forthwith distributed under a Creative Commons Attribution 4.0 International License, which permits use, sharing, adaptation, distribution and reproduction in any medium or format, as long as you give appropriate credit to the original author(s) and the source, provide a link to the Creative Commons licence, and indicate if changes were made. The images or other third party material in this article are included in the article's Creative Commons licence, unless indicated otherwise in a credit line to the material. If material is not included in the article's Creative Commons licence and your intended use is not permitted by statutory regulation or exceeds the permitted use, you will need to obtain permission directly from the copyright holder. To view a copy of this licence, visit http://creativecommons.org/licenses/by/4.0/.

The original article has been corrected.

Open Access This article is licensed under a Creative Commons Attribution 4.0 International License, which permits use, sharing, adaptation, distribution and reproduction in any medium or format, as long as you give appropriate credit to the original author(s) and the source, provide a link to the Creative Commons licence, and indicate if changes were made. The images or other third party material in this article

The original article can be found online at https://doi.org/10.1057/s41292-020-00209-1.

Aryn Martin

aryn@yorku.ca

1 Department of Sociology, York University, 4700 Keele St, Toronto, ON M3J 1P3, Canada 
are included in the article's Creative Commons licence, unless indicated otherwise in a credit line to the material. If material is not included in the article's Creative Commons licence and your intended use is not permitted by statutory regulation or exceeds the permitted use, you will need to obtain permission directly from the copyright holder. To view a copy of this licence, visit http://creativecommons.org/licen ses/by/4.0/.

Publisher's Note Springer Nature remains neutral with regard to jurisdictional claims in published maps and institutional affiliations. 